\title{
MECHANICAL CHARACTERIZATION OF RECYCLED TIRES IN CONCRETE
}

\author{
${ }^{1}$ Mehmet Alpaslan KÖROĞLU \\ ${ }^{1}$ Necmettin Erbakan University, Engineering \& Architectural Faculty, Konya, TURKEY \\ 1makoroglu@konya.edu.tr
}

(Geliş/Received: 21.07.2016; Kabul/Accepted in Revised Form: 20.10.2016)

\begin{abstract}
Waste tires have been an increasing problem every year due to the increase of vehicle sales. The disposal of waste tires has presented very serious problems to the human community in the world. Currently, some research has been studied on not only waste tire chips (WTC) but also recycled steel tire fibres (RSF) in concrete. Present study is focusing on the usage of WTC and RSF in concrete mixture. The different weight of WTC and RSF is mixed in concrete in order to investigate the effect on mechanical properties. By adding WTC and RSF obtained a satisfactory improvement on cracking control, compressive strength, flexural strength and also tensile strength, Moreover, compressive, flexural and tensile strength was positively affected by the addition of WTC and RSF for some mixtures. More percentage of weight fractions added gives high result in tensile strength. However, the workability of the concrete reinforced with both WTC and RSF was negatively affected.
\end{abstract}

Key words: Waste steel fiber, Waste tire chips, Concrete, Compressive strength, Flexural strength

\section{Beton İçindeki Geri Dönüştürülmüş Araç Lastiklerinin Mekanik Özellikleri}

ÖZ: Araç satışlarının artmasıyla birlikte atık lastikler artan bir problem olmaya başladılar. Atık lastiklerin ortadan kaldırılması insular için ciddi problemler ortaya çıkarmaktadır. Günümüzde sadece atık lastik parçalarının (WTC) betonda kullanım değil, atık lastik tellerinin (RSF) de betonda kullanımı araştırılmaktadır. Bu çalışma WTC ve RFS atıklarının beton içinde kullanımını araştırmaktadır. Farklı oranlardaki atıkların betonun mekanik özelliklerine etkisi incelenmektedir. Betona lastik atıklarının katılmasıyla çatlak kontrolünde, basınç dayanımında eğilme ve çekme dayanımlarında iyileşmelerin olduğu görülmüştür. Ayrıca, eğilme çekme dayanımların WTC ve RFS atıklarının katkısıyla pozitif olarak etkilendiği görülmüştür. Atıkların yüzde olarak fazla eklenmesiyle çekme dayanımının artmıştır. Ancak, hem WTC hem de RFS atıklarının ilavesiyle işlenebirlik negatif olarak etkilenmiştir.

Anahtar Kelimeler: Atık çelik fiber, Atık lastik, Beton, Basınç dayanımı, Eğilme dayanımı

\section{INTRODUCTION}

In Turkey, studies in the field of waste management have indicated a significant development especially in the last decades, with expanding social and political sensitivity. Since disposal of waste tires has been a major problem for urban areas all around the world, a hard intensive work is being done in order to recycle waste tires. In general, decomposing waste tires by burning process is presumed as the economical and simple way (Siddique and Naik, 2004). However, the pollution owing to very large quantity of smoke including $\mathrm{CO}_{2}$ makes burning waste tires so unacceptable which is also banned by law in many countries (Gesoğlu et al., 2006). So, innovative processes that are economic and environmental friendly have been developed in order to recycle waste tires. 
Recycling waste tires into civil engineering applications has been obtaining gradually more concerns particularly into asphalt paving mixtures and concrete over the years. Therewithal, other existing practices for recycling waste tires in civil engineering applications are also benefiting tires as lightweight fillers and using whole tires as crash barriers, bumpers and artificial reefs (Shu and Huang, 2014).

Using recycled tires in Portland cement concrete (PCC) has been limited compared to the applications in asphalt paving mixtures because of the negative effect on compressive strength (Huang, et al., 2004). Waste tire rubber chips are used in concrete in place of coarse or fine aggregate with the size ranges from rubber chips ( $25 \mathrm{~mm}$ to $50 \mathrm{~mm}$ ) to crumb rubber powders $(4.75 \mathrm{~mm}$ to $0.075 \mathrm{~mm}$ ).

Topcu (1995) studied the size and amount of tire rubbers on the mechanical properties of concrete. He obtained that the plastic capacity was improved in spite of the compressive strength was decreased. Eldin and Senouci (1993) researched the strength and toughness of concrete with a percent of coarse aggregates displaced with recycled tire chips. The compressive strength and split tensile strength were decreased as the toughness and ability to absorb fracture energy were developed. Lee et al., (1998) studied the flexure and impact strength of crumb rubber-filled concrete. They obtained that crumb rubber-filled concrete had more flexure and impact strength when compared with conventional Portland cement concrete and latex-modified concrete.

Steel fibers are the component separated from rubber by mechanical processes can be used in concrete in order to improve the performance of concrete including ductility, post-cracking behaviour and impact resistance. Using steel fibers separated from rubber would be a good alternative to enhance more economical, environmental friendly and mechanically improved.

Neocleous et al., (2004), Tlemat et al., (2004), (Tlemat et al., 2006a) and (Tlemat et al., 2006b) carried out that steel fibres recovered from waste tires (RSF) can be successfully used to prepare fiber-reinforced concrete (FRC) They studied the pull-out behaviour and the flexural strength of concrete reinforced with recycled steel fibers, industrial steel fibers and pyrolysed RSF recycled steel fibers. Also new tensile stress-strain model to predict the flexural resistance of concrete reinforced with conventional and recycled steel fibers was proposed.

The aim of this study is to investigate the mechanical performance of concrete with waste tire chips and steel tire fibers. By using waste tire chips and waste steel fibers in structural concrete, a number of specimens were prepared. In this way, compressive, tensile and flexural tests on 28-days age of waste steel fiber reinforced concrete were conducted. This paper represents the results of this experimental study.

\section{MATERIALS AND METHOD}

The recycled steel fiber adopted in the present experimental study was supplied by a Turkish private company from Konya, and the crumbing process of waste tires was the one adopted by this company. Both waste tire chips and waste steel fibers were prepared by crumbing and sieved.

\section{Material}

Following materials utilized in the present research:

\section{Cement matrix}

Ordinary Portland cement according to TS EN 197-1, CEM I 32.5 R cement was used for every concrete mixture. Raw materials used in this research include cement, fine aggregate (natural river sand), coarse aggregate and tire fibers. Natural river sand with a maximum size of $5 \mathrm{~mm}$, specific gravity of 1.52 , SSD water absorption of $1.37 \%$, and SSD density of $2512 \mathrm{~kg} / \mathrm{m}^{3}$ was used in this study. Course aggregate with a max a maximum aggregate size of $15 \mathrm{~mm}$ was used. Specific weight of course 
aggregate is found as $2690 \mathrm{~kg} / \mathrm{m}^{3}$ and SSD water absorption of $0.6 \%$. Both natural river sand and course aggregates were batched in a dry condition.

For preparation of all the samples, a water-cement ratio (w/c) of 0.55 (by weight) was used. Table 1 represents the details of the mixture proportions. Since the specific weight of WTC and RSF are different, varied ratio is used for these fibers.

Table 1. Concrete mix design

\begin{tabular}{|cc|c|c|c|c|c|c|c|}
\hline $\begin{array}{c}\text { Sample } \\
\text { RSF }\end{array}$ & $\begin{array}{c}\text { Sample } \\
\text { WTC }\end{array}$ & $\begin{array}{c}\text { Fine } \\
\text { Aggregate } \\
(\mathbf{g r})\end{array}$ & $\begin{array}{c}\text { Course } \\
\text { Aggregate } \\
\mathbf{( g r )}\end{array}$ & $\begin{array}{c}\text { Cement } \\
\text { (gr) }\end{array}$ & Water & $\begin{array}{c}\text { Weight } \\
\text { Percent } \\
\text { (gr) }\end{array}$ & $\begin{array}{c}\text { RSF } \\
\text { (\%) }\end{array}$ & WTC \\
\hline 0 & 0 & 18090 & 22110 & 9900 & 5400 & 0 & 0 & 0 \\
$1 \%$ & $1 \%$ & 18090 & 22110 & 9900 & 5400 & 1 & 555 & 555 \\
$2 \%$ & $2.5 \%$ & 18090 & 22110 & 9900 & 5400 & 2 & 1110 & 1387.5 \\
$3 \%$ & $5 \%$ & 18090 & 22110 & 9900 & 5400 & 3 & 1665 & 2775 \\
\hline
\end{tabular}

All standard steel moulds for cubes, cylinders and prisms specimens has been prepared for oiling the inner surface of the formwork before casting in order to remove the mould after the concrete hardened.

Concrete mixing process was performed to ensure that waste tire chips and steel fibers were distributed uniformly in the concrete mix. In the first stage, all ingredients (cement, fine aggregate, water and course aggregate) were mixed well then after waste tire chips and steel fibers are added gradually.

\section{Slump Test}

In order to obtain workability of fresh concrete mixture slump test is applied to all mixtures (Figure 1). Slump height for the control specimen which is plain concrete is $100 \mathrm{~mm}$. Slump height was decreased since the addition of fiber into concrete mixture. From $1 \%$ until $3 \%$, the slump height was decreasing. Slump height is calculated to be $60 \mathrm{~mm}$ for $1 \%$ of fiber weight, $35 \mathrm{~mm}$ for $2 \%$ of fiber weight and $10 \mathrm{~mm}$ for $3 \%$ of fiber weight. And slump height for WTC specimens is calculated to be $70 \mathrm{~mm}$ for $1 \%$ of fiber weight, $25 \mathrm{~mm}$ for $2,5 \%$ of fiber weight and $5 \mathrm{~mm}$ for $5 \%$ of fiber weight. It is indicates that the slump of the mixture was decreased when waste tire chips and steel tire fiber content increased.

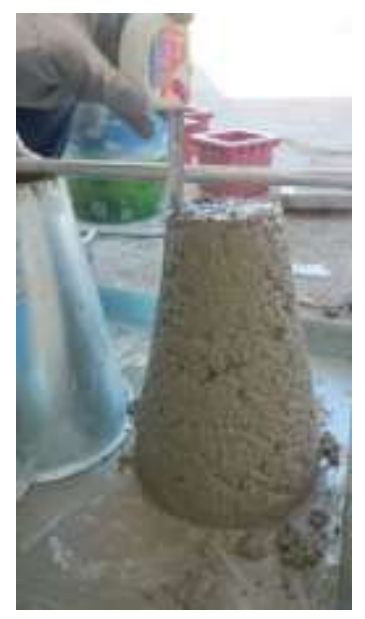

Figure 1. Slump test

The compressive strength test for the cubes was applied at the ages of 28 days. A total of 36 that 18 of WTC and RSF concrete cubes with the dimensions of $150 \times 150 \times 150 \mathrm{~mm}$ were prepared. 3 specimens 
were prepared for each percentage weight fraction of steel fibers $(0.0 \%, 1 \%, 2 \%, 3 \%)$ and waste tire chips $(0.0 \%, 1 \%, 2,5 \%, 5 \%)$. ASTM C 109 is used to determine compressive strength for the concrete that is used in this study (Figure 2.).

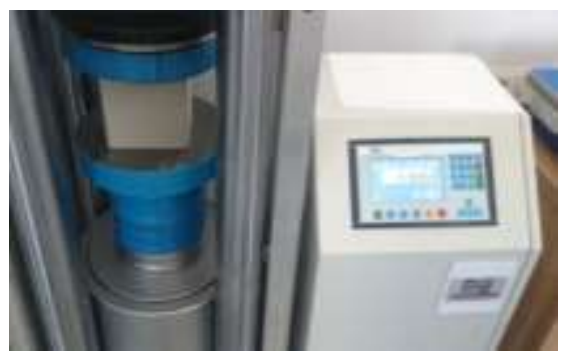

Figure 2. Compressive strength test

A total of 3 prismatic specimens with the overall dimensions of $150 \times 150 \times 400 \mathrm{~mm}$ were tested for each percentage weight fraction of steel tire fibers $(0.0 \%, 1 \%, 2 \%, 3 \%)$ and waste tire chips $(0.0 \%, 1 \%$, $2,5 \%, 5 \%)$. The 3 point flexure test was carried out at the age of 28 days with the standard of ASTM D790.

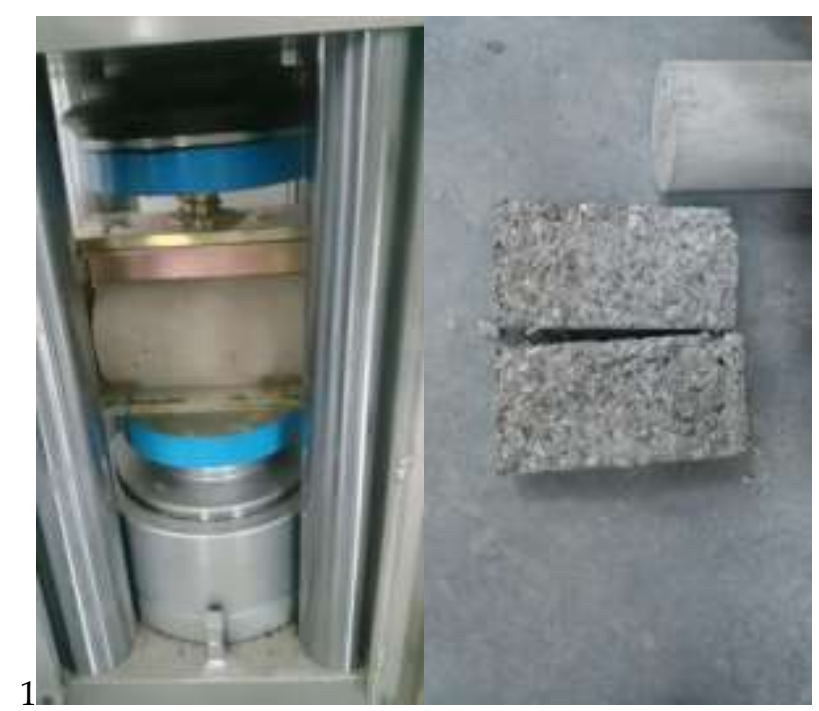

Figure 3. Split tensile test

The results of split tensile strength test were based on cylinders with various weight fraction of tire fiber for 28th days. In the course of split tensile strength test, specimens were tested by applying an increasing load throughout the vertical diameter until split failure occurs. Failure of the specimens comes of along its vertical diameter, owing to tension developed in the transverse direction (Figure 3). 

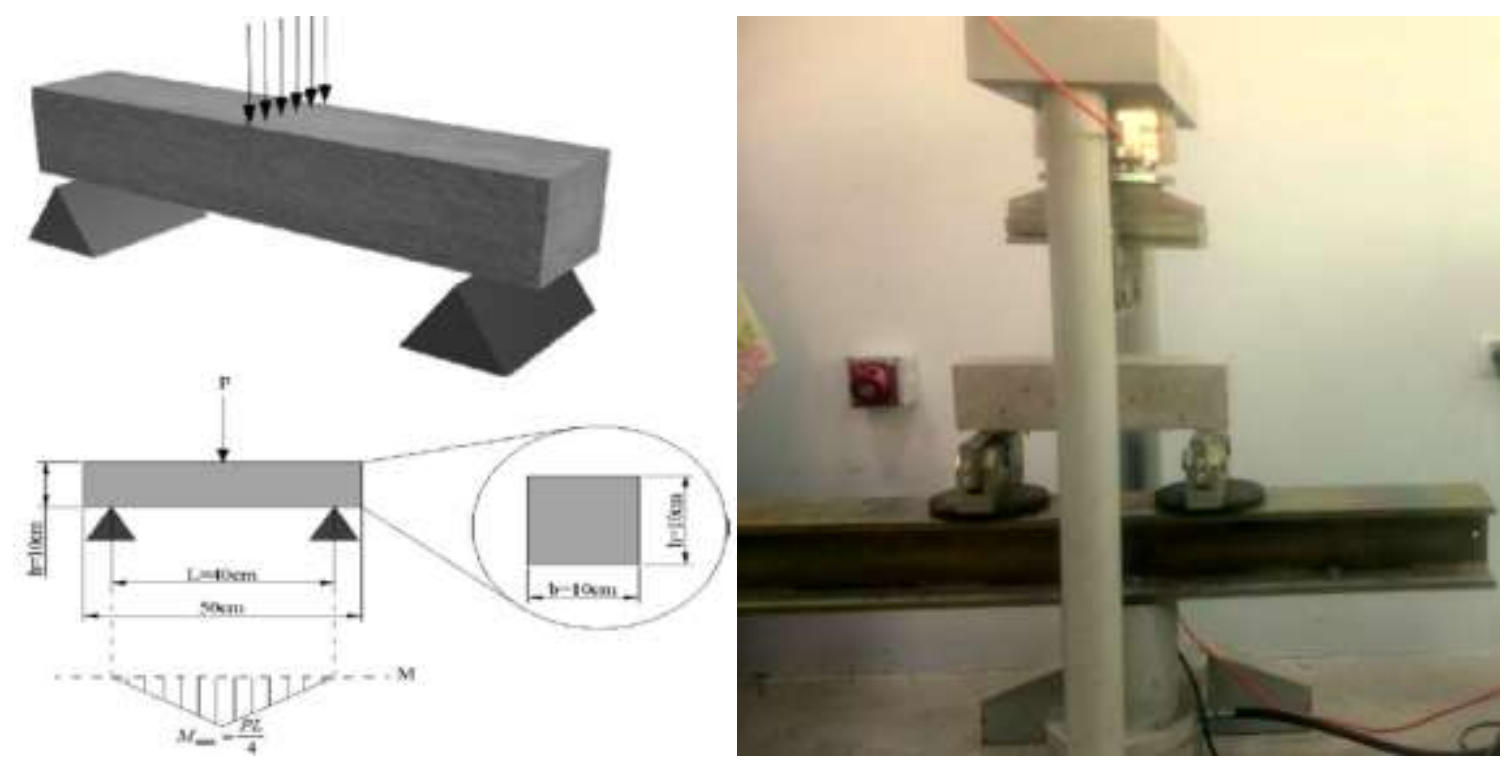

Figure 4. 3 point loading flexural test

The $100 \times 100 \times 500 \mathrm{~mm}$ specimens were cast instead in order to evaluate the flexural tensile strength of concrete. For all the prism samples, the tests for the determination of the fracture energy were obtained with 3 point bending test (Figure 4).

\section{RESULTS}

The concrete properties with different weight fraction of RSF are summarized in Table 2.

Table 2. Concrete properties with different weight fraction of fibers

\begin{tabular}{|c|c|c|c|c|c|}
\hline $\begin{array}{c}\text { Weight of } \\
\text { Fiber } \%\end{array}$ & $\begin{array}{c}\text { Slump } \\
(\mathbf{m m})\end{array}$ & $\begin{array}{c}\text { Unit } \\
\text { Weight } \\
\left(\mathbf{k g} / \mathbf{m}^{3} \mathbf{)}\right.\end{array}$ & $\begin{array}{c}\text { Compressive } \\
\text { Strength (MPa) }\end{array}$ & $\begin{array}{c}\text { Flexural } \\
\text { Strength } \\
\mathbf{( M P a})\end{array}$ & $\begin{array}{c}\text { Tensile } \\
\text { Strength (MPa) }\end{array}$ \\
\hline 0 & 100 & 2210 & 28.05 & 2,99 & 2,36 \\
1 RSF & 60 & 2266 & 28.74 & 3,41 & 2,67 \\
2 RSF & 35 & 2288 & 30.93 & 3,78 & 3,26 \\
3 RSF & 10 & 2315 & 30.14 & 3,04 & 3,14 \\
1 WTC & 70 & 2180 & 26.58 & 3,43 & 2,27 \\
2.5 WTC & 25 & 2153 & 21.45 & 3,25 & 2,09 \\
5 WTC & 5 & 2111 & 17.09 & 2,57 & 1,85 \\
\hline
\end{tabular}

From Table 2. above, the highest average compressive strength is at $2 \%$ which is $30.93 \mathrm{MPa}$ of steel fiber weight whereas the lowest strength is at $0 \%$ which is $28.05 \mathrm{MPa}$. Although stress for $3 \%$ fiber weight sample is lower than $2 \%$ fiber weight sample, the strain is more. Compressive strength for waste tire chips decreasing with weight fraction of tire chips. Flexural strength for weight fraction of tire chips increases for the fraction of $1 \%$ and $2.5 \%$. Figure 5 and Figure 6 shows that increasing fiber content also increase ductility of the concrete. 


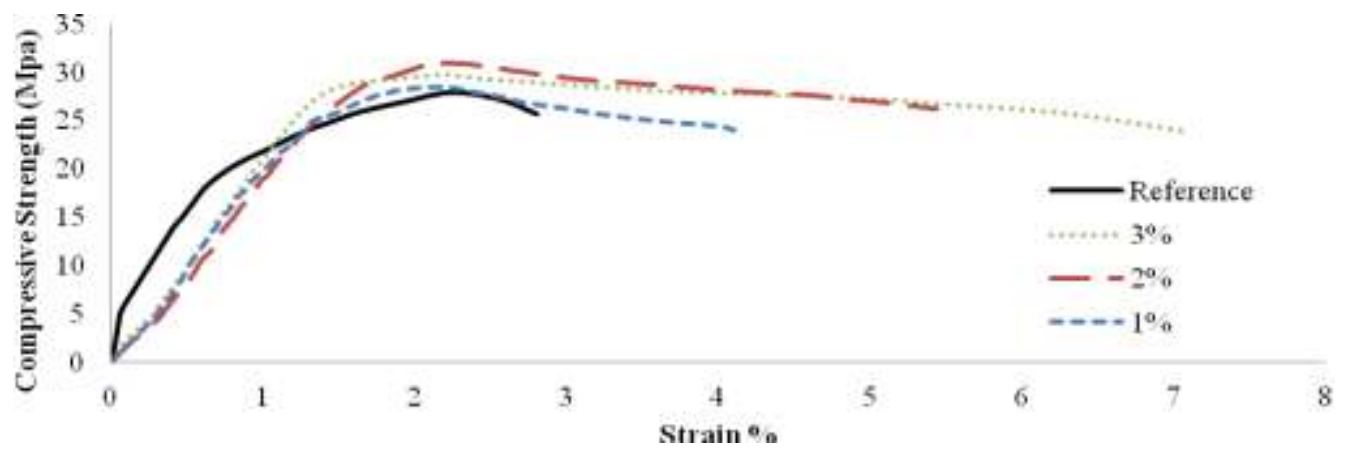

Figure 5. Stress-strain diagram for RSF concrete

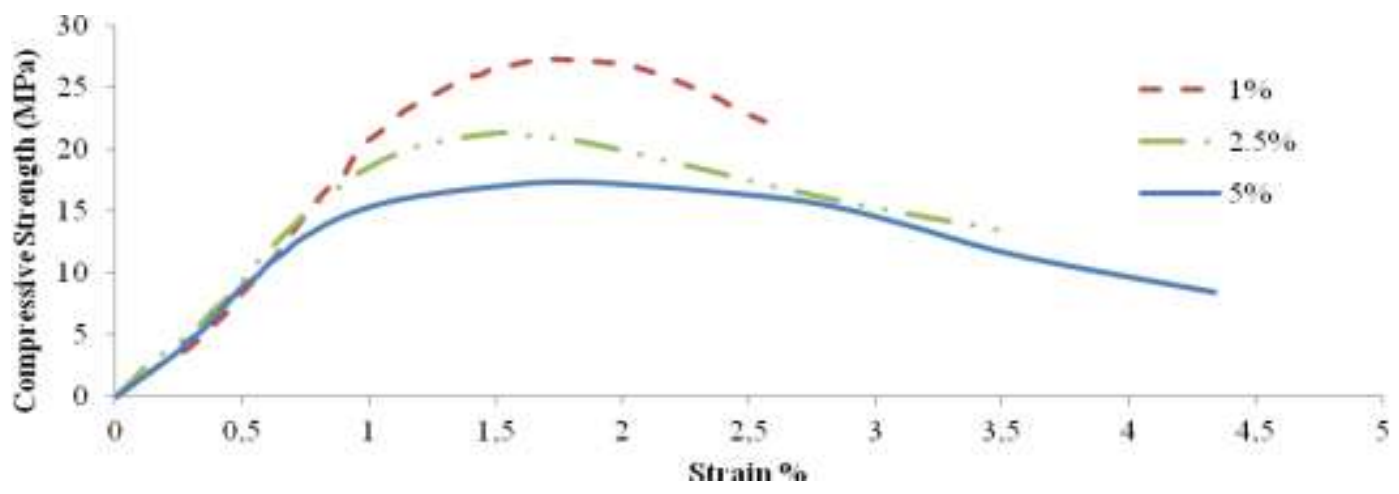

Figure 6. Stress-strain diagram for WTC concrete

Result of tensile strength of the control cylinder is found to be $2.36 \mathrm{MPa}$ and decrease until $3.26 \mathrm{MPa}$ at $2 \%$ and increase again at $3 \%$ which is $3.14 \mathrm{MPa}$ for steel fibers. It is seen from Table 2., the highest flexural strength is at $2.0 \%$ of fibre content which is $3.78 \mathrm{MPa}$ and the lowest strength is at $0 \%$ of fibre volume which is $2.99 \mathrm{MPa}$. Tensile strength for concrete with waste tire chips decreases with weight fraction of tire chips.

The energy dissipation can be calculated by integrating the areas under the load-deflection curves. In this study it is observed that when the fiber contents are increased the area under are increased for both WTC and RSF specimens.

\section{CONCLUSIONS}

This research has proved that the performance of steel tire fiber reinforced concrete is much better compare to conventional plain concrete similarly with the current studies from literature. This experimental study have proved that usage of RSF more than $2 \%$ with weight fraction could maintain voids due to insufficient compaction of concrete. However, both concrete compressive and flexural strength may reduce. Therefore it is essential to design the concrete mix by evaluating steel fiber length and ratio. Waste tire chips fiber reinforced concrete has higher flexural strength and ductility. The conclusions from this research based on the experimental results are:

- The test result shows that as the fiber weight of fraction increase the workability for both fibers tend to decrease significantly. Moreover, it can be realized that, the slump test decreases when the weight of fiber increases.

- Waste steel fiber in concrete may be used in order to increase the mechanical properties of concrete. High percentage of weight fraction gives high flexural strength of the concrete. However, when the fraction is more than $\% 2$ weight segregation of fiber can decrease strength of concrete. 
- The concrete with RSF absorb more energy before and after fail. The recycled tire steel fibers in concrete grips the concrete particles when load is applied on it until failure.

- The crack opening width can be controlled by using RSF in concrete.

- Split tensile test and 3 point flexural test indicate that concrete reinforced with RSF has much greater toughness compared to plain concrete. The cylinder does not split during tensile test since the presence of RSF in concrete. Moreover, concrete prism also does not break into two because of the RSF reinforced in concrete.

\section{REFERENCES}

Eldin N.N., Senouci A.B., 1993, "Rubber-Tire Practices as Concrete Aggregate", Journal of Materials in Civil Engineering, Vol. 5 (4), pp. 478-496.

Gesoğlu M., Güneyisi E., Khoshnaw G., İpek S., 2014, "Investigating Properties Of Pervious Concretes Containing Waste Tire Rubbers", Construction and Building Materials, Vol. 63, pp. 206-213.

Huang B., Li G., Pang Su-Seng, Eggers J., 2004, "Investigation Into Waste Tire Rubber-Filled Concrete", Journal of Materials in Civil Engineering, Vol. 16 (3), pp. 187.

Lee H.S., Lee H., Moon J. S., Jung H. W., 1998, "Development of Tire-Added Latex Concrete", ACI Materials Journal, Vol. 95 (4), pp. 356-364.

Neocleous, K., Tlemat, H., Pilakoutas, K., 2004, “Design Considerations on The Use of Steel Fibres from Waste Tyres, as Reinforcement in Concrete", In: Proceedings of the First International Conference on Innovative Materials and Technologies for Construction and Restoration, Liguori Ed., Lecce, Italy, Vol. 1., pp. 611-619, 6-9 June 2004.

Siddique R., Naik T.R., 2004, "Properties of Concrete Containing Scrap-Tire Rubber - An Overview", Waste Manage, Vol. 24, pp. 563-569.

Shu X., Huang B., 2014, "Recycling of Waste Tire Rubber in Asphalt and Portland Cement Concrete: An Overview", Construction and Building Materials, Vol. 67, Part B, pp. 217-224.

Tlemat H., Pilakoutas K., Neocleous K., “Demonstrating Steel Fibres From Waste Tyres as Reinforcement in Concrete: Material Characterization". In: Proceedings of the First International Conference on Innovative Materials and Technologies for Construction and Restoration, Vol. 1. Liguori Ed., Lecce, Italy, pp. 172-185, 6-9 June 2004.

Tlemat H., Pilakoutas K., Neocleous K., 2006a, “Design Issues for Concrete Reinforced with Steel Fibres Recovered from Waste Tyres", Journal of Materials in Civil Engineering, ASCE, Vol. 18 (5), pp.677-685.

Tlemat H., Pilakoutas K., Neocleous K., 2006b, "Stress Strain Characteristic of SFRC using Recycled Fibre", Materials and Structures, Vol. 39, pp. 365-377.

Topcu I.B., 1995, “The Properties of Rubberized Concretes", Cement and Concrete Research, Vol. 25 (2), pp.304-310. 